\title{
Effect of $\mathrm{P}_{2} \mathrm{O}_{5}$ Additive on Nuclear Radiation Shielding Behaviors of Lithium Aluminum Silicate (LAS) Glass System
}

\author{
Gulfem Susoy ${ }^{1 *}$ \\ ${ }^{1}$ Istanbul University, Faculty of Science, Department of Physics, 34134, Istanbul, Turkey (ORCID: 0000-0002-3760-1999)
}

(First received 1 October 2019 and in final form 29 October 2019)

(DOI: 10.31590/ejosat.638450)

ATIF/REFERENCE: Susoy, G. (2019). Effect of $\mathrm{P}_{2} \mathrm{O}_{5}$ Additive on Nuclear Radiation Shielding Behaviors of Lithium Aluminum Silicate (LAS) Glass System. European Journal of Science and Technology, (17), 530-538.

\begin{abstract}
In this work, shielding parameters of LAS (lithium-aluminum-silicate) $\mathrm{Li}_{2} \mathrm{O}-\mathrm{Al}_{2} \mathrm{O}_{3}-\mathrm{SiO}_{2}$ glass samples have been reported with the help of the WinXCom code, a Windows version of the XCOM database. The effect of increasing $\mathrm{P}_{2} \mathrm{O}_{5}$ concentration on the shielding parameters has been examined in the used $\mathrm{Li}_{2} \mathrm{O}-\mathrm{Al}_{2} \mathrm{O}_{3}-\mathrm{SiO}_{2}$ glass samples. The shielding effectuality of the materials for gamma-ray can be interpreted with the help of several different attenuation parameters which plays key role in understanding the shielding capabilities of the material. The mass attenuation coefficient, defined by $\mu_{m}=\mu / \rho$, is the most basic coefficient used to calculate the shielding parameters. These parameters are the mean free path (MFP), half value layer (HVL), tenth value layer (TVL), effective electron number $\left(\mathrm{N}_{\mathrm{e}}\right)$ and equivalent atomic number $\left(\mathrm{Z}_{\mathrm{eq}}\right)$. The exposure buildup factor $(\mathrm{EBF})$ and GP fitting parameters are also calculated by the method of logarithmic interpolation using $\mathrm{Z}_{\mathrm{eq}}$ of a $\mathrm{Li}_{2} \mathrm{O}-\mathrm{Al}_{2} \mathrm{O}_{3}-\mathrm{SiO}_{2}$ glass system. The EBF values for $\mathrm{Li}_{2} \mathrm{O}-\mathrm{Al}_{2} \mathrm{O}_{3}-\mathrm{SiO}_{2}$ glass samples show an inverse relation with $\mathrm{N}_{\mathrm{e}}$. Further, $\mathrm{P} 1$ (least $\mathrm{N}_{\mathrm{e}}$ ) offers maximum values of EBF and P6 (highest $\mathrm{N}_{\mathrm{e}}$ ) offers minimum EBF values. The change in different shielding parameters for the selected glasses was interpreted by considering three interactions with the substance (Photoelectric effect, Compton scattering and pair production). The obtained results show that the $\mu_{m}$ strongly depends on the photon energy, chemical composition and density of the shielding materials. It is clear to see that P6 glass sample having the highest $\mathrm{P}_{2} \mathrm{O}_{5}$ concentration is the most effective glass sample among the other glasses of $\mathrm{Li}_{2} \mathrm{O}-\mathrm{Al}_{2} \mathrm{O}_{3}-\mathrm{SiO}_{2}$ system in nuclear radiation shielding ability.
\end{abstract}

Keywords: $\mathrm{P}_{2} \mathrm{O}_{5}$; gamma shielding; EBF;

\section{$\mathbf{P}_{2} \mathbf{O}_{5}$ Katkılı Lityum Alüminyum Silikat (LAS) Cam Sistemlerinin Nükleer Radyasyon Zırhlamasına Etkisi}

$\ddot{O} \mathbf{z}$

$\mathrm{Bu}$ çalışmada, XCOM veritabanının Windows sürümü olan WinXCom programı kullanılarak LAS (lityum-alüminyum-silikat) Li 2 O$\mathrm{Al}_{2} \mathrm{O}_{3}-\mathrm{SiO}_{2}$ cam örneklerinin zırhlama parametreleri hesaplanmıştır. Kullanılan cam örneklerinde $\mathrm{P}_{2} \mathrm{O}_{5}$ konsantrasyonunun artan yüzde oranının zırhlama parametreleri üzerindeki değişim etkisi incelenmiştir. Gama 1şını için malzemelerin koruyusu etkisi, malzemelerin zırhlama etkilerini anlamada kilit rol oynayan birkaç farklı zırhlama parametresi yardımıyla yorumlanabilir. $\mu_{m}=\mu / \rho$ ile tanımlanan kütle zayıflama katsayısı, zırhlama parametrelerini hesaplamak için kullanılan en temel katsayıdır. Bu parametreler ortalama serbest yol (MFP), yarı değer katmanı (HVL), onuncu değer katmanı (TVL), etkili elektron numarası $\left(\mathrm{N}_{\mathrm{e}}\right)$ ve eşdeğer atom numarasıdır $\left(\mathrm{Z}_{\mathrm{eq}}\right)$. Ayrica maruz kalma faktörü (EBF) ve GP fitleme parametreleri de $\mathrm{Li}_{2} \mathrm{O}-\mathrm{Al}_{2} \mathrm{O}_{3}-\mathrm{SiO}_{2}$ cam örnekleri için logaritmik enterpolasyon yöntemi ve $\mathrm{Z}_{\mathrm{eq}}$ değerinin kullanılması ile hesaplanmıştır. $\mathrm{Li}_{2} \mathrm{O}-\mathrm{Al}_{2} \mathrm{O}_{3}-\mathrm{SiO}_{2}$ cam örnekleri için EBF değerleri, $\mathrm{N}_{\mathrm{e}}$ ile ters bir ilişki göstermektedir. Ayrıca, P1 cam örneği için EBF değeri maksimum değeri alırken (en az $\mathrm{N}_{\mathrm{e}}$ ), P6 cam örneği için minimum EBF değeri (en yükssek $\mathrm{N}_{\mathrm{e}}$ ) hesaplanır. Seçilen camlar için farklı zırhlama parametrelerinde gözlenen değişiklik, madde ile üç etkileşim göz önünde bulundurularak yorumlanmaktadır bu etkileşimler fotoelektrik etki, Compton saçılması ve çift oluşumdur. Elde edilen sonuçlar, kütle zayıflatma katsayısı $\left(\mu_{m}\right)$ değerinin fotonun enerjisine, cam örneklerinin kimyasal bileşimine ve zırhlama malzemelerinin yoğunluğuna

${ }^{*}$ Corresponding Author: Istanbul University, Faculty of Science, Department of Physics, 34134, Istanbul, Turkey, ORCID: 0000-0002-3760-1999, glfmsusoy972@gmail.com 
bağlı olduğunu göstermektedir. En yüksek $\mathrm{P}_{2} \mathrm{O}_{5}$ konsantrasyonuna sahip olan $\mathrm{P} 6$ cam numunesinin diğer $\mathrm{Li}_{2} \mathrm{O}-\mathrm{Al}_{2} \mathrm{O}_{3}-\mathrm{SiO}_{2}$ cam örnekleri arasından nükleer radyasyon koruma kabiliyeti bakımından en etkili cam numunesi olduğunu açıkça görülmektedir.

Anahtar Kelimeler: $\mathrm{P}_{2} \mathrm{O}_{5}$; gamma zirhlama; EBF.

\section{Introduction}

Ionizing radiations such as gamma-ray and x-ray are widely used in different fields such as medical, industrial and nuclear medicine [1]. The main idea in radiation protection is to know tolerable doses and to prevent radiation workers and the surrounding population from taking doses above it. The obstacle to be placed between the radiation source and the person will minimize the dose taken. The armor chosen for the different types of radiation must be different. The higher the material density and atomic number, the more protective it is against radiation [2]. Radiation protection refers to the principle of ALARA, known as As Low As Reasonably Achievable which means, it is necessary to administer a minimum dose which is reasonable. ALARA principle is applied according to three basic parameters; time (as little time as possible), distance (as far as possible) and shielding $[3,4]$. The calculation of radiation shielding depends on the type of radiation source, the location and energy dependence of the radiation, the mechanisms of radiation interaction with matter, and the determination of secondary radiation sources released as a result of the interaction of radiation [5]. Many properties of this material need to be studied to select the material to be used to reduce the effect of photon radiation. For this purpose, the linear attenuation coefficients $(\mu)$ of the substances are examined as a measure of the absorption of a photon by the substance. The linear attenuation coefficient gives the possibility of a photon passing any interaction per unit length; it is the sum of the possibilities of photoelectric attenuation $(\tau)$, Compton scattering $(\sigma)$ and double formation $(\kappa)$. Today, the majority of these materials are made of lead and lead-containing composites; however, lead has some disadvantages. First of all, these materials are heavy and this may cause some negligence in their use. On the other hand, the toxic effect of lead used in these materials and the fact that the lead has a brittle structure shortens the service life of the protective material [6]. In order to overcome this disadvantageous situation, the demand for glass materials as alternative materials is increasing [7-11]. Glass-ceramic materials have the same chemical composition as glass, but have a different structure from them. That is, typically $95-98 \%$ by volume is crystalline, while a small percentage is glassy. Glass ceramic materials are typically characterized by certain properties. Some of those; high power, low-even sometimes negative thermal expansion coefficient, high impact resistance, good resistance to thermal shock, and a range of optical properties. $\mathrm{LAS}\left(\mathrm{Li}_{2} \mathrm{O}-\mathrm{Al}_{2} \mathrm{O}_{3}-\mathrm{SiO}_{2}\right)$, a combination of lithium aluminum silicate, is one of the most valuable and widely used glass-ceramic systems. This glass system has a wide range of useful features such as low thermal expansion coefficient (TEC), excellent mechanical properties and high thermal shock resistance [12-14]. It is an important step to add different nucleating agents (such as oxides) to reduce the crystallization temperature of glassceramic materials and limit the tendency to convert. The nucleating agents used repeatedly $\mathrm{are}_{\mathrm{ZrO}_{2}}$ and $\mathrm{TiO}_{2}$ oxides [15-16]. In addition, the effect of the use of $\mathrm{P}_{2} \mathrm{O}_{5}$ oxides, known as high moisture absorbing and small crystalline glass makers such as boric oxide and silicon dioxide, has been particularly investigated in LAS glass ceramics. Also, the glass-ceramic sample contains a small amount of MgO to reduce the melting point and a low concentration of lithium to reduce the cost of the material. Among the various types of oxides, phosphorus pentoxide $\left(\mathrm{P}_{2} \mathrm{O}_{5}\right)$ known as highly hygroscopic and microcrystalline glass network former like boric oxide and silicon dioxide. On the other hand, $\mathrm{P}_{2} \mathrm{O}_{5}$ can be doped with rare earth and metals to manufacture special glasses such as medical implants for insoluble acid-resistance as well as for radiation shielding [17]. In this study, it is aimed to observe the nuclear radiation shielding properties of $\mathrm{P}_{2} \mathrm{O}_{5}$ additive on LAS (lithium-aluminum-silicate) glasses. In order to interpret these properties, several gamma-ray shielding parameters have been identified with exposure buildup factor (EBF) for five LAS glass samples with different $\mathrm{P}_{2} \mathrm{O}_{5}$ doped [18]. In this study, the WinXCom program was used to determine the mass attenuation coefficients of glass samples [19]. Other important gamma ray shielding parameters were calculated by using mass attenuation coefficients obtained by the WinXCom program. These parameters are, mean free path (MFP), half value layer (HVL), tenth value layer (TVL), effective electron number $\left(\mathrm{N}_{\mathrm{e}}\right)$ and exposure buildup factor (EBF), respectively. Table 1 shows the density and molar percentages of $\mathrm{P}_{2} \mathrm{O}_{5}$ doped Lithium Aluminum Silicate (LAS) glass samples. The results from recent studies may provide a better understanding of the effect of the $\mathrm{P}_{2} \mathrm{O}_{5}$ additive on nuclear radiation shielding, and may also bring a different perspective to research on $\mathrm{P}_{2} \mathrm{O}_{5}$ oxide.

Table 1. Chemical Properties of the Investigated Glasses

\begin{tabular}{cccccccccc}
\hline $\begin{array}{c}\text { Sample } \\
\text { Code }\end{array}$ & $\mathrm{SiO}_{2}$ & $\mathrm{Al}_{2} \mathrm{O}_{3}$ & $\mathrm{Li}_{2} \mathrm{O}$ & $\mathrm{MgO}$ & $\mathrm{ZrO}_{2}$ & $\mathrm{TiO}_{2}$ & $\mathbf{P}_{2} \mathrm{O}_{5}$ & $\mathrm{Sb}_{2} \mathrm{O}_{3}$ & $\begin{array}{c}\text { Density } \\
\left(\mathbf{g} / \mathbf{c m}^{3}\right)\end{array}$ \\
\hline P2 & 59 & 25.5 & 4 & 4 & 2 & 2 & 2 & 1.5 & 2.516 \\
\hline P3 & 59 & 24.5 & 4 & 4 & 2 & 2 & 3 & 1.5 & 2.519 \\
\hline P4 & 59 & 23.5 & 4 & 4 & 2 & 2 & 4 & 1.5 & 2.523 \\
\hline P5 & 59 & 22.5 & 4 & 4 & 2 & 2 & 5 & 1.5 & 2.528 \\
\hline P6 & 59 & 21.5 & 4 & 4 & 2 & 2 & 6 & 1.5 & 2.539 \\
\hline
\end{tabular}




\section{Material and Method}

\subsection{WinXCom Program}

Theoretically calculated mass attenuation coefficient values are given as tables in the study conducted by Hubbell and Seltzer [20]. A suitable alternative method for manual calculations is to generate the attenuation data required by the computer. The tables in the above-mentioned study are used for these calculations. With this in mind, Berger and Hubbell [21] improved a computer program called $\mathrm{XCOM}$ for the calculation of attenuation coefficients and cross-sections for any element, mixture or compound in the energy region of $1 \mathrm{keV}-100 \mathrm{GeV}$. There have been a number of updates to this program since then, and now a web version is also available. Lately, this well-known and widely used program has been adapted by Gerward et al. Into the Windows infrastructure, and the Windows version is called WinXCom $[22,25]$.

\subsection{Calculation method of shielding parameters}

The $\mu_{m}=\mu / \rho$ (mass attenuation coefficient) coefficient is a non-density-dependent coefficient and is calculated according to the law of Lambert-Beer for the attenuating materials examined.

$$
\mu_{m} x=\ln \left(\frac{I}{I_{0}}\right)
$$

where $I_{0}, I$ and $\mathrm{x}$ are the incident photon intensity, attenuated photon intensity and thickness of the sample, respectively. On the other hand, the $\mu_{m}\left(\mathrm{~cm}^{2} / \mathrm{g}\right)$ values of compounds and mixture of different elements are theoretically formulated with the help of the mixture rule [26] defined by equation 2 .

$$
\left(\mu_{m}\right)=\sum_{i} w_{i}\left(\mu_{m}\right)_{i}
$$

where $w_{i}$ and are $\left(\mu_{m}\right)_{i}$ the weight fraction and mass attenuation coefficient of the ith element. The $\mu_{m}$ values of the sample glasses might be calculated for specific energy values with the help of the WinXCom program.

The effective atomic number $\left(Z_{\text {eff }}\right)$ of the sample glasses can be calculated by taking the ratio of the total atomic and electronic cross-sections.

$$
Z_{\text {eff }}=\frac{\sigma_{t, a}}{\sigma_{t, e l}}=\frac{\frac{1}{N_{A}} \sum_{i} f_{i} A_{i}\left(\frac{\mu}{\rho}\right)_{i}}{\frac{1}{N_{A}} \sum_{i} \frac{f_{i} A_{i}}{Z_{i}}\left(\frac{\mu}{\rho}\right)_{i}}
$$

In the equation 3, the $\mathrm{N}_{\mathrm{A}}$ is Avogadro constant, $f_{i}$ is the fractional abundance of $i$ th element and $A_{i}$ is the atomic weight of the $i$ th element. The effective number of electrons is calculated by the following formula.

$$
N_{e}=\frac{(\mu / \rho)}{\sigma_{t, e l}}=\frac{N_{A} Z_{\text {eff }}}{\langle A\rangle} ;\langle A\rangle=\frac{M}{\sum_{i} n_{i}}
$$

\subsection{Essential theoretical parameters for gamma-ray shielding}

To describe the radiation shielding efficiency for glass samples the essential theoretical parameters like HVL, TVL and MFP are interpreted for gamma-ray shielding. The HVL, TVL and MFP can be calculated by the mass attenuation coefficient $\left(\mu_{m}\right)$ presented in Eq. 5-6-7;

$$
\begin{aligned}
& H V L=\frac{0.693}{\mu_{m} \rho} \\
& T V L=\frac{\ln 10}{\mu_{m} \rho} \\
& M F P=\frac{1}{\mu_{m} \rho}
\end{aligned}
$$

\subsection{The exposure buildup factor}

While a single element has the atomic number $Z$, the compound materials have the equivalent atomic number $\left(Z_{\mathrm{eq}}\right)$ and describe the properties of glass systems. The $Z_{\mathrm{eq}}$ was used for calculating the exposure buildup factors (EBF) and the G-P fitting parameters.

$$
Z_{e q}=\frac{Z_{1}\left(\log R_{2}-\log R\right)+Z_{2}\left(\log R-\log R_{1}\right)}{\log R_{2}-\log R_{1}}
$$

where the $R_{1}$ and $R_{2}$ are the ratio of $\left(\mu_{m}\right)_{\text {compton }} /\left(\mu_{m}\right)_{\text {total }}$ and $Z_{1}$ and $Z_{2}$ refer the atomic numbers of the glass samples. G.P fitting parameters $\left(b, c, a, X_{k}, d\right)$ for the glass samples were achieved by interpolation of equation 8 and detailed calculation procedures can be found from many studies [27-30]. Detailed studies on shielding parameter calculations are available [31-34]. 


\section{Results and Discussion}

Initially, theoretical calculations was used to compare the $\mu_{m}$ measurement results of the samples. For the calculation, the WinXCom code in the energy region of $0.015 \mathrm{MeV}-15 \mathrm{MeV}$ were used (can be seen in Table 2). The variation of $\mu_{m}$ values according to glass samples can be seen in Figure 1. The figure shows a quick decrease in the MAC values of the sample glasses to $0.03 \mathrm{MeV}$. The reason for this is that at low energies, the photon interacts with the substance in relation to $Z^{4} / \mathrm{E}^{3.5}$. Then, as the photon energy value increases, a slower decrease is observed [35-37]. This is because Compton scattering and pair production processes are predominant in medium and high photon energies depending on $\mathrm{Z}$ and $\mathrm{Z}^{2}$. Finally, the glass sample P6 possesses the highest $\mu_{m}$ values among the studied glasses.

Table 1. Mass Attenuation Coefficients $\left(\mu_{m}\right)$ for the Glass Samples Estimated by WinXCom Program

\begin{tabular}{cccccc}
\hline $\mathbf{E}(\mathbf{M e V})$ & \multicolumn{5}{c}{ MAC $\left(\boldsymbol{\mu}_{\boldsymbol{m}}\right)$ (WinXCom) } \\
\cline { 2 - 6 } & $\boldsymbol{P 2}$ & $\mathbf{P 3}$ & $\mathbf{P 4}$ & $\mathbf{P 5}$ & $\mathbf{P 6}$ \\
\hline 0,015 & 6,5163 & 6,5299 & 6,5436 & 6,5573 & 6,5710 \\
\hline 0,02 & 3,7895 & 3,7955 & 3,8014 & 3,8074 & 3,8133 \\
\hline 0,03 & 1,3003 & 1,3020 & 1,3038 & 1,3056 & 1,3074 \\
\hline 0,04 & 0,8697 & 0,8704 & 0,8712 & 0,8720 & 0,8727 \\
\hline 0,05 & 0,5382 & 0,5386 & 0,5390 & 0,5394 & 0,5398 \\
\hline 0,06 & 0,3837 & 0,3839 & 0,3841 & 0,3844 & 0,3846 \\
\hline 0,08 & 0,2517 & 0,2518 & 0,2519 & 0,2520 & 0,2521 \\
\hline 0,10 & 0,1986 & 0,1987 & 0,1987 & 0,1988 & 0,1989 \\
\hline 0,15 & 0,1487 & 0,1487 & 0,1488 & 0,1488 & 0,1488 \\
\hline 0,20 & 0,1285 & 0,1285 & 0,1285 & 0,1286 & 0,1286 \\
\hline 0,30 & 0,1077 & 0,1077 & 0,1077 & 0,1077 & 0,1078 \\
\hline 0,40 & 0,0954 & 0,0954 & 0,0954 & 0,0954 & 0,0954 \\
\hline 0,50 & 0,0867 & 0,0867 & 0,0867 & 0,0867 & 0,0867 \\
\hline 0,60 & 0,0800 & 0,0800 & 0,0800 & 0,0800 & 0,0800 \\
\hline 0,80 & 0,0701 & 0,0701 & 0,0701 & 0,0701 & 0,0701 \\
\hline 1,00 & 0,0630 & 0,0630 & 0,0630 & 0,0630 & 0,0630 \\
\hline 1,50 & 0,0513 & 0,0513 & 0,0513 & 0,0513 & 0,0513 \\
\hline 2,00 & 0,0442 & 0,0442 & 0,0442 & 0,0442 & 0,0442 \\
\hline 3,00 & 0,0360 & 0,0360 & 0,0360 & 0,0360 & 0,0360 \\
\hline 4,00 & 0,0314 & 0,0314 & 0,0314 & 0,0314 & 0,0314 \\
\hline 5,00 & 0,0285 & 0,0285 & 0,0285 & 0,0285 & 0,0285 \\
\hline 6,00 & 0,0266 & 0,0266 & 0,0266 & 0,0266 & 0,0266 \\
\hline 8,00 & 0,0241 & 0,0241 & 0,0241 & 0,0241 & 0,0241 \\
\hline 10,00 & 0,0227 & 0,0227 & 0,0227 & 0,0227 & 0,0227 \\
\hline 15,00 & 0,0212 & 0,0212 & 0,0212 & 0,0212 & 0,0212 \\
\hline & & & & &
\end{tabular}

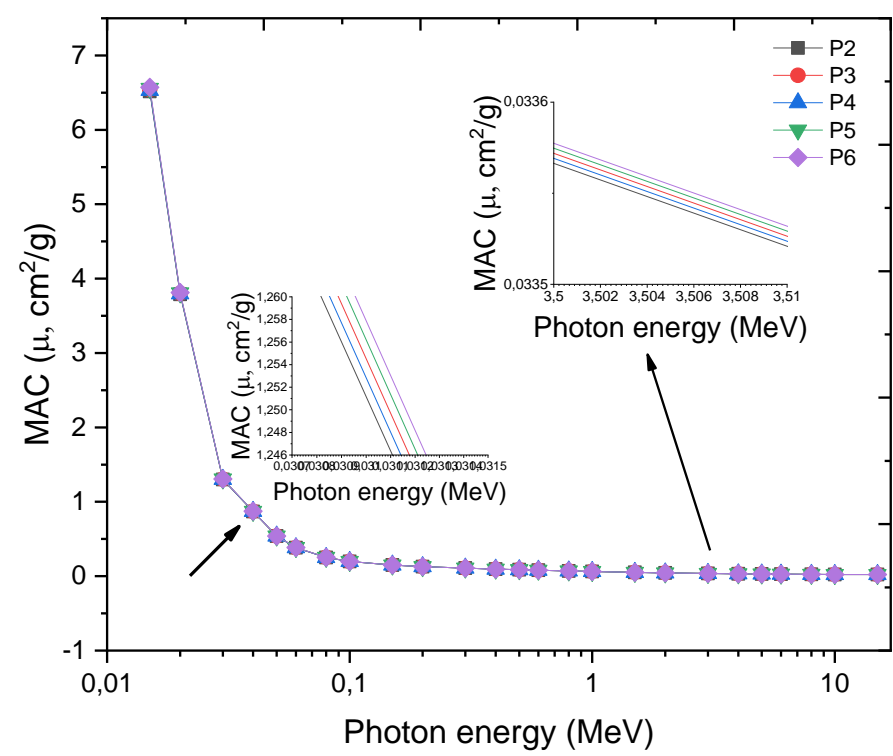

Figure 1. Mass attenuation coefficients $\left(\mu_{m}\right)$ of the sample glasses with photon energy from 0.015 to $15 \mathrm{MeV}$. 
There are three main parameters used to specify the material thickness in selected photon energy, as well as to forecast the ability of the glass samples to be studied, such as MFP, HVL and TVL. Low values indicate superior protection ability. As can be seen from Figures 2 and 3 the $\mathrm{P} 6$ glass sample having the highest energy and maximum $\mathrm{P}_{2} \mathrm{O}_{5}$ composition was found to reduce MFP, HVL and TVL values of $\mathrm{Li}_{2} \mathrm{O}-\mathrm{Al}_{2} \mathrm{O}_{3}-\mathrm{SiO}_{2}$ glass system and improve the gamma attenuation capacity.

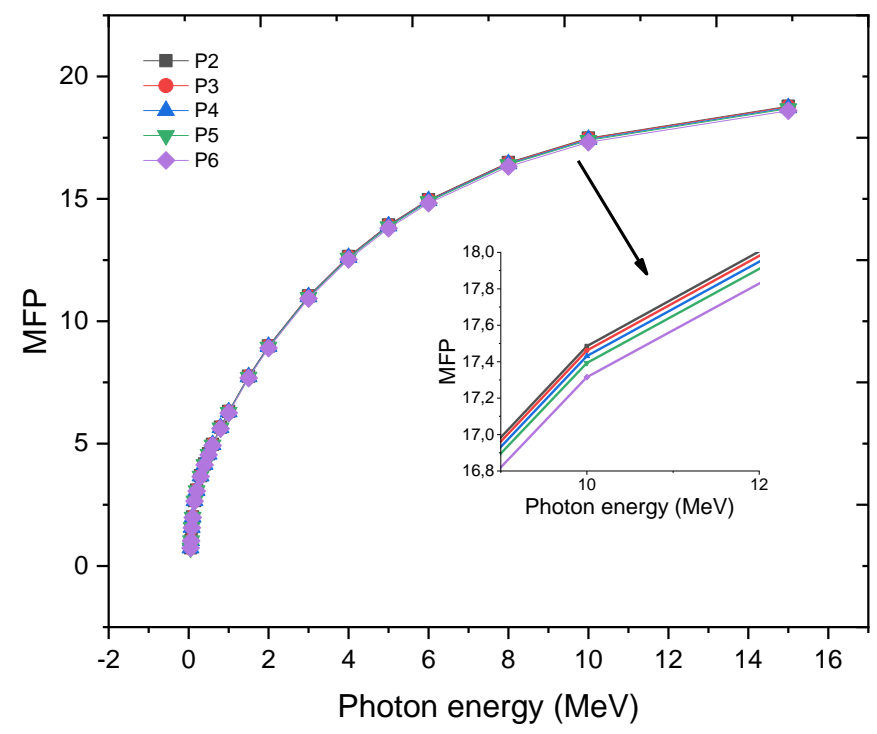

Figure 2. Mean free path (MFP) of investigated glass samples.

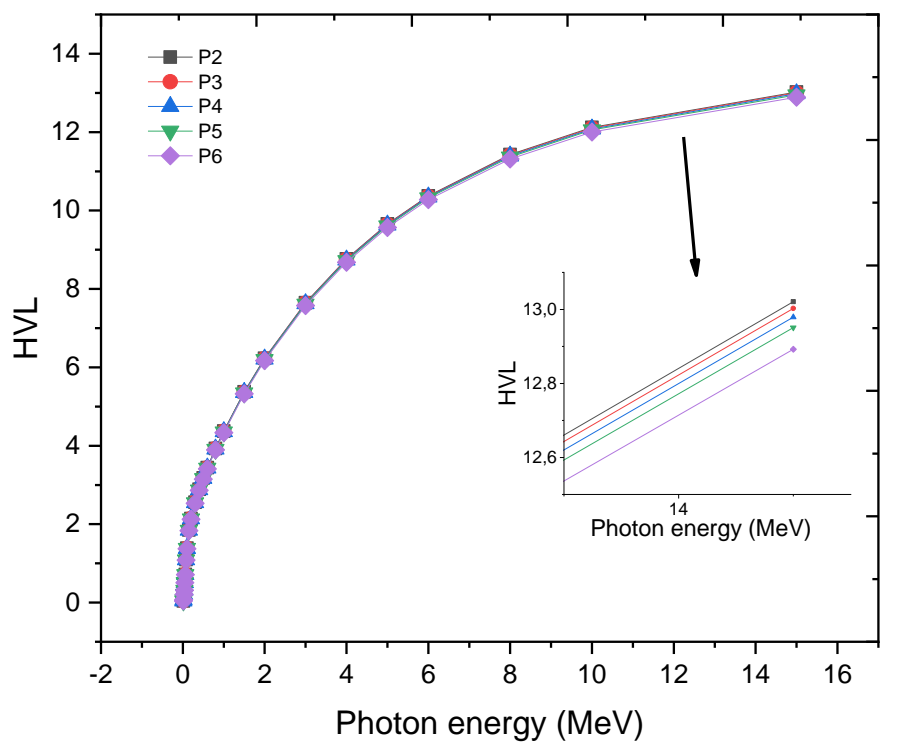

a)

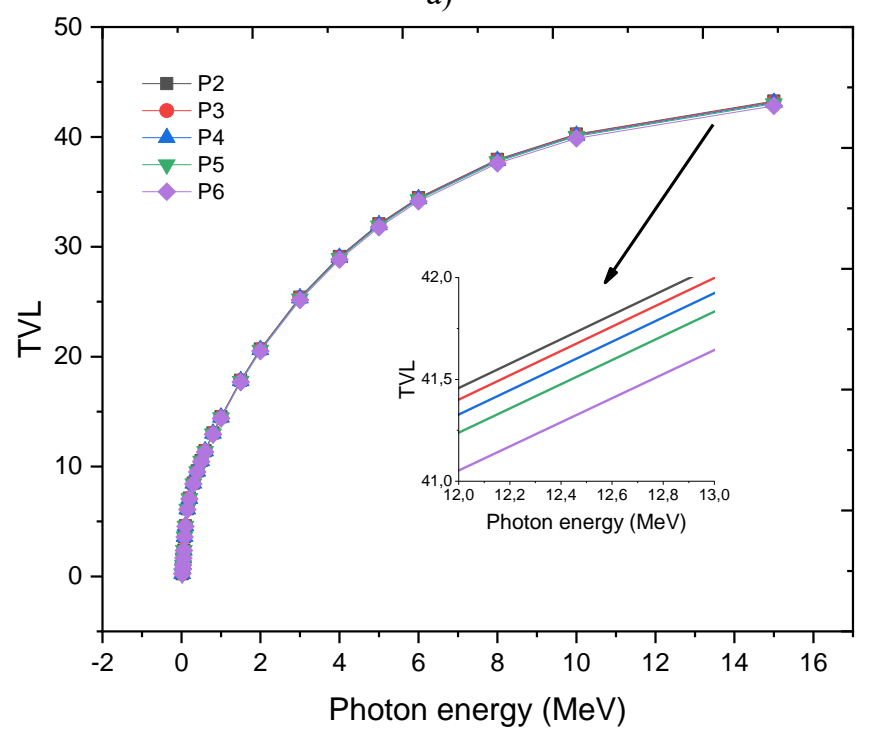

b)

Figure 3. a)Half (HVL) and b) tenth value layer (TVL) of investigated glass samples. 
The variation of MFP values for P2, P3, P4, P5, P6 glass samples are in the region of $0.06099-18.78489,0.06079-18.75868,0.06057$ - 18.72511, 0.06033- 18.68425, $0.05994-18.5995$ respectively.

Figure 4 shows the $\mathrm{N}_{\mathrm{e}}$ values of $\mathrm{Li}_{2} \mathrm{O}-\mathrm{Al}_{2} \mathrm{O}_{3}-\mathrm{SiO}_{2}$ glass samples that vary with photon energy and elemental composition of glass samples. As can be clearly seen from the figure, the $\mathrm{N}_{\mathrm{e}}$ values are highest in the low energy zone and a sudden drop is observed after $0.1 \mathrm{MeV} . \mathrm{N}_{\mathrm{e}}$ values slightly increase after $1.022 \mathrm{MeV}$ energy value which is dominated by the pair production process. In addition, $\mathrm{N}_{\mathrm{e}}$ values increase with the increase of $\mathrm{P}_{2} \mathrm{O}_{5}$ in $\mathrm{Li}_{2} \mathrm{O}-\mathrm{Al}_{2} \mathrm{O}_{3}-\mathrm{SiO}_{2}$ glass system according to Figure 4 the sample $\mathrm{P} 2$ has the maximum $\mathrm{N}_{\mathrm{e}}$ value among the samples and these values vary between 4.8702-3.2496.

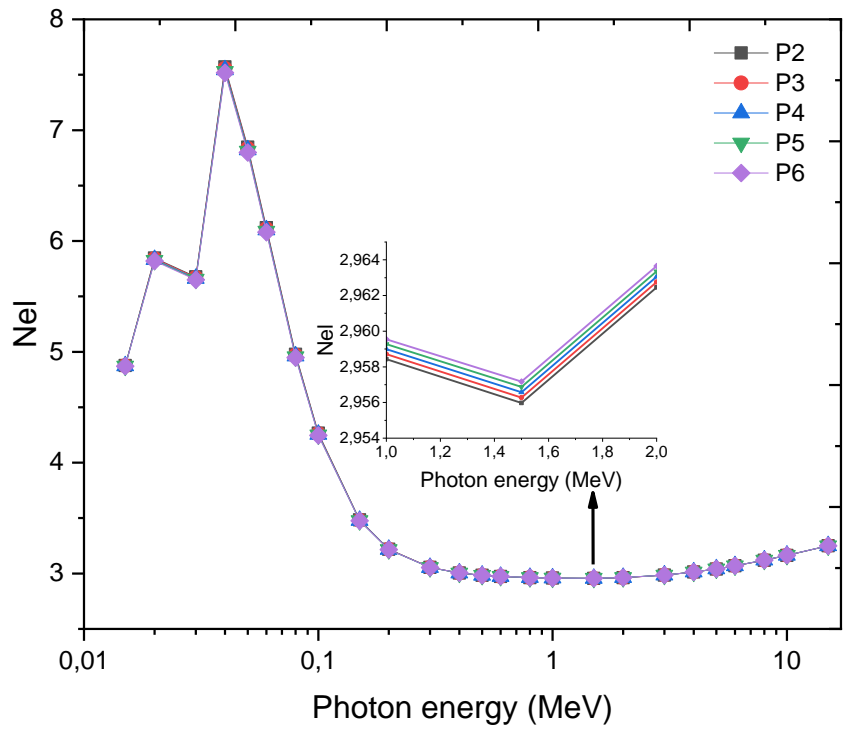

Figure 4. Effective electron density $\left(N_{e l}\right)$ of the glass samples with photon energy

Variation of equivalent atom numbers $Z_{\text {eq }}$ of glass samples for photon energies region from $0.015 \mathrm{MeV}$ to $15 \mathrm{MeV}$ can be seen in Figure 5. With the highest $Z_{\mathrm{eq}}$ value, $\mathrm{P} 6$ yields the minimum EBF values. The Figure 6 represents the EBF variations of P2-P3-P4-P5-P6 glass samples at different photon energies using penetration depths 1,2, 5, $10 \mathrm{mfp}$. As in the other graphs examined in this study, EBF graphs show the effect of partial photon interactions. When all glass samples are taken into consideration, EBF values take the smallest values at low energies. On the other hand, it is beholded that these values are higher in the middle and high energy regions. As can be seen from the Figure 6, the increase and decrease in EBF factors are due to different processes depending on photon energy. However, the heavy elements in the elemental composition of glasses cause an increase in the cross-section values of pair production and lead to the formation of more secondary photons. Therefore, especially in high penetration depths, EBF values are increased.

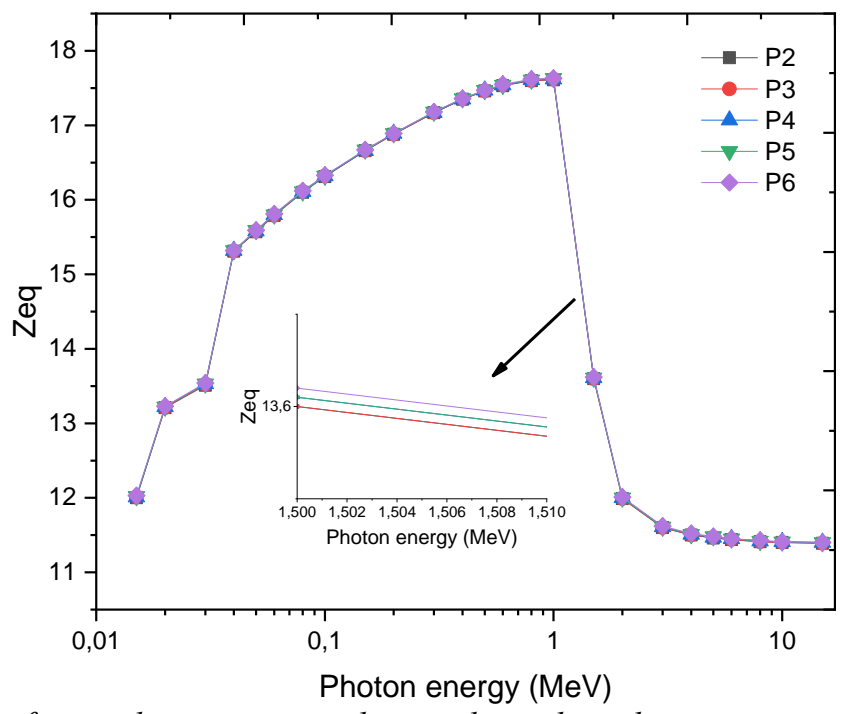

Figure 5. Evaluation of equivalent atomic numbers with incident photon energy range of 0.015-15 MeV 

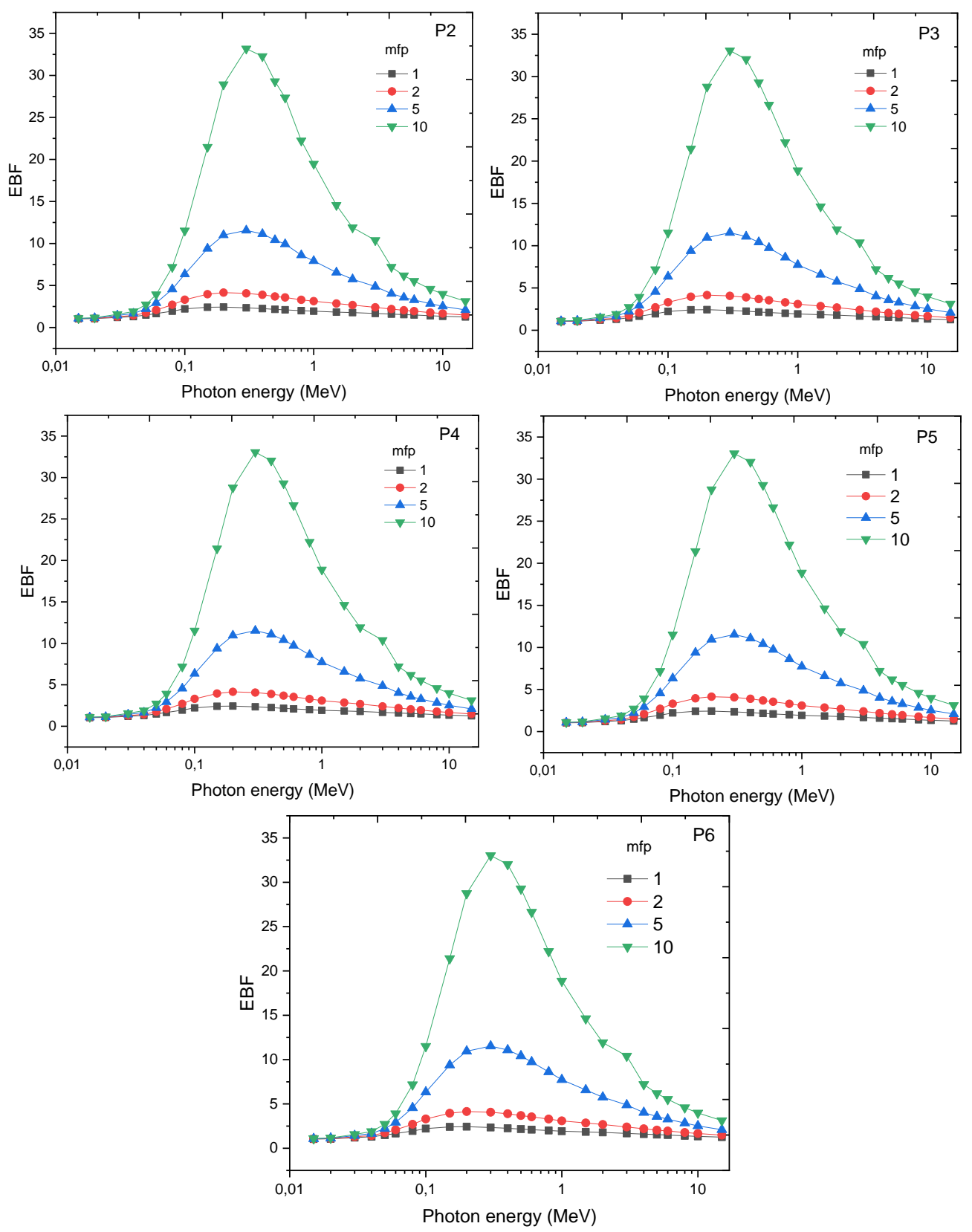

Figure 6. The exposure buildup factors in the energy region 0.015-15 MeV up to $10 \mathrm{mfp}$ for the sample glasses

\section{Conclusions}

In this work, shielding parameters of LAS (lithium-aluminum-silicate) $\mathrm{Li}_{2} \mathrm{O}-\mathrm{Al}_{2} \mathrm{O}_{3}-\mathrm{SiO}_{2}$ glass system reported with the help of the WinXCom program in the photon energy region of $0.015-15 \mathrm{MeV}$. We examine the impact of $\mathrm{P}_{2} \mathrm{O}_{5}$ addition on shielding parameters. The shielding effectuality of the materials for gamma ray can be interpreted with the help of several different parameters. These are the mass attenuation coefficient $\left(\mu_{\mathrm{m}}\right)$, mean free path (MFP), half value layer (HVL), tenth value layer (TVL), effective electron number $\left(\mathrm{N}_{\mathrm{e}}\right)$, equivalent atomic number $\left(\mathrm{Z}_{\mathrm{eq}}\right)$ and exposure buildup factor $(\mathrm{EBF})$. According to the results, it can be understood clearly that the P6 glass sample having the highest $\mathrm{P}_{2} \mathrm{O}_{5}$ addition is the most effective glass sample among the other glasses of $\mathrm{Li}_{2} \mathrm{O}-\mathrm{Al}_{2} \mathrm{O}_{3}-\mathrm{SiO}_{2}$ system in nuclear radiation protection. In addition, when $\mathrm{P}_{2} \mathrm{O}_{5}$ contribution increases in $\mathrm{Li}_{2} \mathrm{O}-\mathrm{Al}_{2} \mathrm{O}_{3}-\mathrm{SiO}_{2}$ glass system, the density of glass samples also increases. This suggests that the P6 glass sample in ther present work is useful shielding material for protection from gamma rays. 


\section{References}

1. Abuzaid, MM., Elshami, W., Steelman, C., (2018). Measurements of Radiation Exposure of Radiography Students During Their Clinical Training Using Thermoluminescent Dosimetry. Radiat Prot Dosimetry, 179(3): 1-4.

2. Trattner, S., Pearson, G. D. N., Chin, C., Cody, D. D., Gupta, R., Hess, C. P., et al. (2014). Standardization and Optimization of Computed Tomography Protocols to Achieve Low-Dose. J Am Coll Radiol [Internet], 11(3): 271-8. Available from: http://www.imagewisely.org

3. ICRP. International Commission on Radiological Protection. (2009) Annual Report.

4. Commission E. (2019). Technical Recommendations for Monitoring Individuals Occupationally Exposed to. Radiat Prot No 160:128.

5. Kavaz, E., Tekin, H. O., Agar, O., Altunsoy, E. E., Kilicoglu, O., Kamislioglu, M., et al. (2019). The Mass Stopping Power / Projected Range and Nuclear Shielding Behaviors of Barium Bismuth Borate Glasses and Influence of Cerium Oxide. Ceramacis International 45:15348-15357. https://doi.org/10.1016/j.ceramint.2019.05.028

6. Ngaile, J. E., Uiso, C. B. S., Msaki, P., Kazema, R., (2008). Use of Lead Shields for Radiation Protection of Superficial Organs in Patients Undergoing Head CT Examinations. Radiat Prot Dosimetry, 130(4):490-8.

7. Tekin, H.O., Kavaz, E., Papachristodoulou, A., Kamislioglu, M., Ağar, O., Altunsoy Guclu, E. E., Kilicoglu, O., Sayyed, M.I. Characterization of SiO2-PbO-CdO-Ga2O3 Glasses for Comprehensive Nuclear Shielding Performance: Alpha, Proton, Gamma, Neutron Radiation. Ceramics International. Available Online: 18 June 2019. https://doi.org/10.1016/j.ceramint.2019.06.168

8. Kilicoglu, O., Altunsoy, E.E., Agar, O., Kamislioglu, M., Sayyed, M.I., Tekin, H.O., Tarhan, N., (2019). Synergistic Effect of La2O3 on Mass Stopping Power (MSP)/Projected Range (PR) and Nuclear Radiation Shielding Abilities of Silicate Glasses. Results in Physics 14: 102424. https://doi.org/10.1016/j.rinp.2019.102424

9. Sayyed, M.I., Ali, A.A. Tekin, H.O., Rammah.Y.S., (2019), Investigation of Gamma-Ray Shielding Properties of Bismuth Borotellurite Glasses Using MCNPX Code and XCOM Program. Applied Physics A 125: 445. https://doi.org/10.1007/s00339019-2739-x

10. Tekin, H.O., Kavaz, E., Altunsoy, E.E., Kamislioglu, M., Kilicoglu, O., Agar, O., Sayyed, M.I., Tarhan, N., (2019), Characterization of a Broad Range Gamma-Ray and Neutron Shielding Properties of MgO-Al2O3-SiO2-B2O3 and Na2O-Al2O3SiO2 Glass Systems. Journal of Non-Crystalline Solids, 518: 92-102. https://doi.org/10.1016/j.jnoncrysol.2019.05.012

11. Kavaz, E., Tekin, H.O., Yildiz Yorgun, N., Ozdemir, O. F., Sayyed, M.I., (2019), Structural and Nuclear Radiation Shielding Properties of Bauxite Ore Doped Lithium Borate Glasses: Experimental and Monte Carlo Study. Radiation Physics and Chemistry 162: 187-193. https://doi.org/10.1016/j.radphyschem.2019.05.019

12. Rawlings, R.D., Wu, J.P., Boccaccini, A.R., (2006). Glass-ceramics: Their Production From Wastes-a Review, J. Mater. Sci. 41: 733-761.

13. James, P.F., (1995). Glass-ceramic: New Compositions and Uses, J. Non-Cryst. Solids 181:1-15.

14. Tick, P.A., Borrelli, N.F., Reaney, I.M., (2000), Relationship Between Structure and Transparency in Glass-Ceramic Materials, Opt. Mater. 15(1):81-91.

15. Gua, X., Yang, H., Cao, M., (2005). Nucleation and Crystallization Behaviour of LAS System Glass-Ceramics Containing Little and no Fluorine, J. Non-Cryst. Solids 351:2133-2137.

16. Hoche, T., et al., (2011). ZrTiO4 Crystallization in Nanosized Liquid-Liquid Phase-Separation Droplets in Glass - A Quantitative XANES Study, 13: p. 2550.

17. Sayyed, M.I., Khattari, Z.Y., Kumar, A., Al-Jundi, J., Dong, M.G., AlZaatreh, M.Y., (2018), Radiation Shielding Parameters of BaO-Nb2O5-P2O5 Glass System Using MCNP5 Code and XCOM Software. Materials Research Express, 5(11). https://doi.org/10.1088/2053-1591/aaddc7

18. Jiaqi, W., Changwei, L., Jianlei, L., Lei, H., Hua, G., Cui, L., Taoyong, L., Anxian, L., (2019), The Effect of Complex Nucleating Agent on the Crystallization, Phase Formation and Performances in Lithium Aluminum Silicate (LAS) Glasses. Journal of NonCrystalline Solids 521:119486. https://doi.org/10.1016/j.jnoncrysol.2019.119486

19. Gerward, L., Guilbert, N., Jensen, K.B. and Levring, H. (2004). WinXCom-A Program for Calculating X-Ray Attenuation Coefficients. Radiation Physics and Chemistry, 71: 653-654. http://dx.doi.org/10.1016/j.radphyschem.2004.04.040.

20. Hubbell, J. H., Seltzer, S. M., (1995). Tables of X-ray Mass Attenuation Coefficients and Mass Energy Absorption Coefficients 1 $\mathrm{keV}$ to $20 \mathrm{MeV}$ for Elements $\mathrm{Z}=1-92$ and 48 Additional Substances of dosimetric Interest, NISTIR. 5632.

21. Berger, M. J, Hubbell, J. H., (1987/1999). XCOM: Photon Cross Sections Database, Web Version 1.2, Available at http://physics.nist.gov/xcom. National Institute of Standards and Technology, Gaithersburg, MD 20899, USA. (Originally published as NBSIR 87-3597 'XCOM: Photon Cross Sections on a Personal Computer')

22. Gerward, L., Guilbert, N., Jensen, K. B., (2001). Levring H. X-ray Absorption in Matter. Reengineering XCOM. Radiat Phys Chem., 60: 23-24.

23. Sayyed, M.I., Tekin, H.O., Kılıcoglu, O., Agar, O., Zaid, M. H. M., (2018), Shielding Features of Concrete Types Containing Sepiolite Mineral: Comprehensive Study on Experimental, XCOM and MCNPX results. Results Phys. 11: 40.

24. ANSI/ANS 6.4.3, (1991). Gamma-ray Attenuation Coefficient and Buildup Factors for Engineering Materials. American Nuclear Society.

25. Kaur, S. A., Singh, P.S., Singh, T., (2016), Scope of Pb-Sn Binary Alloys as Gamma Rays Shielding Material, Prog. Nucl. Energy. doi:10.1016/j.pnucene.2016.08.022.

26. Sayyed, M. I., Qashou, S. I., Khattari, Z.Y., (2017). Radiation Shielding Competence of Newly Developed TeO2-WO3glasses, J. Alloys Compd. doi:10.1016/j.jallcom.2016.11.160.

27. Ekinci, N., Kavaz, E., Aygün, B., Perişanoğlu, U., (2019), Gamma Ray Shielding Capabilities of Rhenium-Based Superalloys, 
Radiat. Eff. Defects Solids.0150:1-17. doi:10.1080/10420150.2019.1596110.

28. Issa, S. A. M., Tekin, H. O., · Erguzel, T. T., Susoy, G., (2019). The Effective Contribution of PbO on Nuclear Shielding Properties of xPbO-(100 - x)P2O5 Glass System: A Broad Range Investigation. Applied Physics A, 125 (640): 2-16. https://doi.org/10.1007/s00339-019-2941-x

29. Tekin, H. O., Kilicoglu, O., The influence of gallium (Ga) additive on nuclear radiation shielding effectiveness ofPd/Mn binary alloys. Journal of Alloys and Compounds. 815 (2020) 152484. https://doi.org/10.1016/j.jallcom.2019.152484

30. M.I. Sayyed, H.O. Tekin, O. Agar. Gamma photon and neutron attenuation properties of $\mathrm{MgO}-\mathrm{BaO}-\mathrm{B} 2 \mathrm{O} 3-\mathrm{TeO} 2-\mathrm{Cr} 2 \mathrm{O} 3$ glasses: The role of TeO2. Radiation Physics and Chemistry. 163 (2019) pp. 58-66. https://doi.org/10.1016/j.radphyschem.2019.05.012

31. A. Aydogmuş Erik, E.Kavaz, Serkan Ilkbahar, U.Kara, C. E.Erik, H.O. Tekin. Structural and photon attenuation properties of different types of fiber post materials for dental radiology applications. Results in Physics 13 (2019) 102354. https://doi.org/10.1016/j.rinp.2019.102354

32. Susoy, G., Effect of TeO2 Additions on Nuclear Radiation Shielding Behavior of Li2O-B2O3-P2O5-TeO2 Glass-System, Ceramics International. Available Online: 12 October 2019 https://doi.org/10.1016/j.ceramint.2019.10.108

33. Cebecioglu, R., Yildirim, M., Akagunduz, D., Korkmaz, I., Tekin, H.O., Atasever-Arslan B., Catal T., (2019). Synergistic Effects of Quercetin and Selenium on Oxidative Stress in Endometrial Adenocarcinoma Cells. Bratisl Med J,120(6):449 - 455. doi:10.4149/BLL_2019_72

34. Sayyed, M. I., Kumar, A., Tekin, H.O., Kaur, R., Singh, M., Agar, O., Khandaker, M. U., (2020), Evaluation of Gamma-ray and Neutron Shielding Features of Heavy Metals Doped Bi2O3-BaO-Na2O-MgO-B2O3 Glass Systems. Progress in Nuclear Energy 118 103118. https://doi.org/10.1016/j.pnucene.2019.103118

35. Issa, A. M. S., Tekin, H. O., (2019), The Multiple Characterization of Gamma, Neutron and Proton Shielding Performances ofxPbO-(99-x)B2O3-Sm2O3 Glass 3 System. Ceramics $\quad$ International. 45 2356123571. https://doi.org/10.1016/j.ceramint.2019.08.065

36. Tekin, H.O., Kassab, L. R. P., Issa, A. M. S., Bordon, C. D. S., Altunsoy Guclu, E. E., da Silva Mattos, G.R., Kilicoglu, O., (2019). Synthesis and Nuclear Radiation Shielding Characterization of Newly Developed Germanium Oxide and Bismuth Oxide Glasses. Ceramics International. 45: 24664-24674. https://doi.org/10.1016/j.ceramint.2019.08.204

37. Kilicoglu, O., Tekin, H.O., Bioactive Glasses and Direct Effect of Increased K2O Additive for Nuclear Shielding Performance: A Comparative Investigation. Ceramics International. Available $\quad$ Online: 11 September 2019, https://doi.org/10.1016/j.ceramint.2019.09.095 